\title{
Обман рынков
}

Почти тридцать лет Россия методом мучительных проб и дорогостоящих ошибок ищет «путь в тумане» - ту траекторию развития, которая обеспечивала бы и развитие экономики, и улучшение условий жизни и деятельности ее граждан.

Вступая на путь преобразований во второй половине 1980-х, мы все верили в то, что привнесение в экономику страны рыночных отношений избавит и ее самое, и социальную сферу от излишних и далеких от необходимости затрат. Этому будут способствовать два важнейших обстоятельства: а) появление реальных измерителей различных факторов и условий осуществления социально-экономической деятельности (иными словами - «справедливых» цен, определяемых не в тиши кабинетов плановых органов, а в результате рыночных трансакций); б) раскрепощение предпринимательского духа нашего народа (в результате установления частной собственности на средства производства).

Однако на новом пути страна столкнулась с множеством сложностей и неблагоприятных факторов. Одна из наиболее острых проблем - это увеличивающийся разрыв между возможностями экономики и современными потребностями социальной сферы. России все труднее поддерживать приемлемый уровень государственных пенсий, так же как ранее принятые возрастные ограничения пенсионного возраста. С этими проблемами диссонируют растущее имущественное и социальное неравенство, а также колоссальные накопления, скопившиеся на счетах учреждений финансового сектора страны.

Весь спектр причин, которые привели нашу экономику и социальную сферу к подобным результатам, невозможно представить на страницах журнала. Но если выйти на уровень максимального обобщения, представляется, что ключевые наши ошибки на пути к рынку связаны с попытками... обмануть рынок.

Декларируя создание рыночно-ориентированной экономики и социального государства как важнейшего ее агента, мы очень скоро отошли от ее важнейшего постулата - наличия объективных или близких к таковым измерителей экономической и социальной деятельности.

Следует отметить, что данная проблема актуальна не только для России, но в той или иной мере для всех стран и экономик. Так, например, французский исследователь П. Сален отмечает, что «денежная политика разрушает информацию, которую в обычном случае 
сообщают цены, и ведет к непроизводительной трате ресурсов в силу развития отдельных секторов за счет других, тогда как эта новая структура не соответствует тому, что действительно желают индивиды в нормальных условиях... нельзя безнаказанно обманывать рынки» ${ }^{1}$. Он подчеркивает, что «...именно государственное вмешательство привело к дестабилизации рынков и спровоцировало кризис» ${ }^{2}$, и констатирует: «регламентирование уничтожает ответственность» ${ }^{3}$.

Между тем в России по мере того, как продвижение по пути рыночных преобразований сталкивалось с интересами все новых «групп влияния», государственное вмешательство в экономику только росло, экономические измерители все дальше отходили от содержания реальных процессов и объективно складывающейся относительной ценности различных факторов. Неизбежным следствием этого стали усиливающаяся с каждым годом регламентация всевозможных сфер хозяйственной и социальной деятельности и нарастание степени «обмана рынка».

Наиболее сложная ситуация складывается в сфере государственных расходов. Наши авторы с горечью констатируют, что «... комплексная оценка эффективности бюджетных расходов во многих случаях возможна лишь путем проведения аудита эффективности... и предполагает не только проведение огромной подготовительной работы, включая разработку специальной методики, но и привлечение ведущих отраслевых экспертов, и проведение обширных мониторинговых исследований» (интервью А. Р. Валеева). Очевидно, однако, что специальные методики лишь в малой степени помогают «обмануть рынок» и обеспечить рост эффективности расходов говорить об этом сегодня нет особых оснований.

Современное социальное государство предполагает не только учет интересов всех групп граждан страны, но и осуществление органами власти своих функций в рамках социального контракта с обществом. Наличие подобного контракта позволяет не только избежать чиновничьего произвола и безудержного нормотворчества (как правило, нацеленного на обман рынка), но и отчасти компенсировать реальные провалы рынка - прежде всего, за счет участия в подготовке и реализации нормативных решений «широких слоев общественности».

${ }^{1}$ Сален П. Вернуться к капитализму, чтобы избежать кризисов/ Пер. с фр. Д. Калечкина. М.: Изд-во Института Гайдара, 2005. 272 с. [С. 143].

${ }^{2}$ Там же. С. 11.

${ }^{3}$ Там же C. 64. 
В этой сфере наши достижения тоже пока более чем скромные и в основном ограничиваются благоустройством отдельных фрагментов среды проживания. «...Вовлечение граждан в процесс управления обустройством городских общественных пространств стало одним из предметов очередного указа президента, предусматривающего, в частности, “создание механизма прямого участия граждан в формировании комфортной городской среды, увеличение доли граждан в решении вопросов развития городской среды, до 30\%”» (статья Е.А. Капогузова и А. А. Ковеченковой).

Следствием «обмана рынка» является и то, что «...финансовые потоки перетекают больше в центр, чем возвращаются обратно. Минимальный процент возврата из федерального бюджета характерен для нефтегазодобывающих автономных округов и крупных экономически развитых субъектов РФ ... поступления из малого числа регионов образовывают значительную часть налоговых доходов федерального бюджета» (статья В.В. Климанова, Д.А. Еремина и А.А. Михайлова).

Вполне обоснованно в этой связи звучит извечный русский вопрос «Что делать?». Универсального рецепта, увы, нет и быть не может. Наиболее очевидным представляется решение - восстановить в правах всех участников экономических и социальных процессов. Это означает - учет интересов общества, бизнеса и государства (как выразителя интересов тех правящих элит, которых оно в наибольшей степени представляет). Неправомерной является ситуация, в рамках которой, например, «...изменения в законодательстве о госзакупках были направлены на учет интересов ведомств и не принимали во внимание запросы участников закупочного процесса» (статья А.А. Яковлева, А.В. Ткаченко, О.Н. Балалаевой и Ю.Д. Родионова).

Однако современные информационные технологии, с внедрением которых многие в нашем обществе связывают надежды на усиление прозрачности экономических процессов и даже уход из состояния «обмана рынка», это не более чем новые инструментальные возможности. Об этом говорит и российский, и зарубежный опыт. Без определения роли и места общества и реальной (не виртуальной) экономики в оценке условий и факторов социально-экономического развития вернуть «доверие рынка» не представляется возможным.

Главный редактор «ЭКО»

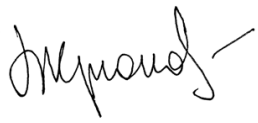

КРЮКОВ B.A. 